\title{
2 Georg Borgström and the population-food dilemma
}

\author{
Reception and consequences \\ in Norwegian public debate \\ in the 1950s and 1960s
}

Sunniva Engh

\begin{abstract}
I have been to many meetings and heard many lectures, but hardly anything has made a stronger impact than this, on 18 March 1968. The Student Union was crowded. People were standing along the walls and in the corridors. The lecture hall was quiet as a grave - a breathless attention, soon followed by wild applause. ${ }^{1}$
\end{abstract}

This 2018 description by Svein Sundsbø of Georg Borgström's lecture, "Agriculture and the World Hunger Crisis", delivered 50 years earlier at the Norwegian Agricultural College at Ås reveals Borgström's enormous, lasting appeal. To the students, Borgström was an international academic superstar who spoke with transformative effect about the issues that mattered to the 1968 generation. According to Borgström, the world's population explosion created food shortages, which, in combination with unjust international distribution and the exhaustion of natural resources, would lead to a global crisis. The world had, at most, ten years to choose a different course and save humanity from a dismal future. The career of Sundsbø, the 1968 president of the student union at Ås, illustrates the effect of Borgström's message: he has dedicated his professional life to public service, as secretary general of the Centre Party and as minister for agriculture 1985-1986, focusing in particular on matters of climate, energy, and environment.

How did Georg Borgström (1912-1990) come to make such an impression on Sundsbø and other Norwegians in 1968? A Swedish plant physiologist and scientist, Borgström earned his $\mathrm{PhD}$ in botany at the University of Lund in 1939. After running the research labs of a private company in the 1940s, Borgström became the director of the Swedish Institute for Conservation Research. In 1956, he left Sweden for a professorship at Michigan State University. His numerous publications addressing the population-food dilemma include Jorden vårt öde: Kan en permanent världhunger avvärjas? (1953), Mat för miljarder (1962), Gränser för vår tillvaro (1962), The Hungry Planet (1965), Revolution i världsfisket (1966), Too Many: A Biological Overview of the World's Limitations (1969), and The Food and People Dilemma (1973).

Inspired by recent historical research on the circulation of knowledge, ${ }^{2}$ this chapter explores the reception by the Norwegian media of Borgström's ideas 
from the 1950s to the early 1970s. It examines particularly when, how, and with what consequences Borgström's message and expertise circulated in Norway. The timing of the attention given to Borgström's research is relevant as he raised the spectre of an overpopulation-resource crisis well ahead of popular and widely read works such as Paul Ehrlich's The Population Bomb $b^{3}$ and Garrett Hardin's article "The Tragedy of the Commons", ${ }^{4}$ both published in 1968. The audience for Borgström's ideas is also significant, as well as the parts of his message that the media focused on. Which milieus were interested in Borgström's work and ideas, and what caused his appeal to Norwegian audiences? Finally, it is also important to consider the consequences, if any, of the Norwegian attention to Borgström and his message.

A considerable literature exists on concerns in Scandinavia about population and their relation to domestic social and national policies and legislation. ${ }^{5}$ There is also a growing literature on the transnational circulation of knowledge and political interactions regarding population and resources, beginning in interwar scientific collaboration and geopolitical thinking ${ }^{6}$ and continuing, with shifting emphases, in the Cold $\mathrm{War}^{7}$ and beyond. ${ }^{8}$ The population-resource dilemma has also been studied as the precursor to the American environmental movement. ${ }^{9}$ Scandinavia's political interest in population growth and support for population control programmes in the global south have been noted by researchers. ${ }^{10}$ Work is emerging on Scandinavian scientists' interest in resource matters ${ }^{11}$ with the most comprehensive study to date being Björn-Ola Linnér's The World Household: Georg Borgström and the Postwar Population-Resource Crisis (1998). ${ }^{12}$ Linnér focuses on Borgström's role as a "conveyor of knowledge" disseminating American science to Sweden. ${ }^{13}$ Yet little is known about the impact and circulation of Borgström's research outside Sweden, either in the neighbouring Nordic countries or internationally.

This chapter focuses on Borgström's impact in one country - Norway - and is based on material from the Norwegian National Library's digital newspaper collection, a near-complete archive of all Norwegian newspapers, local and national, since $1763 .{ }^{14}$ Borgström is mentioned three separate times in the late 1940s. During the 1950s, media coverage increases with 66 articles pertaining to Borgström. Attention peaks in the 1960s, with 1,301 mentions, and drops to just over 520 in the 1970s. A search in Norwegian academic journals produces 3 mentions of Borgström during the 1950s, 32 in the 1960s, and 45 in the 1970s. ${ }^{15}$ Borgström and his research thus appear to have attracted far more attention from the popular press than from academic journals.

\section{Old debates, new contexts: from Malthus to Borgström}

Although Borgström achieved a kind of superstar status in 1968 in Norway, his fundamental message was not new. Over 150 years earlier, in 1798, Thomas Malthus' An Essay on the Principle of Population raised concerns about the relationship between population and food. Highlighting how population growth rates could increase exponentially while food production would grow linearly, 
Malthus argued that increases in the food supply would rapidly be outstripped by the demands of an increasing population. Malthusianism continued to find adherents in the nineteenth and twentieth centuries, but it was never uncontested. Additionally, concerns revolved around population composition, quality, and growth rates as well as relative population sizes, raising geopolitical concerns and prompting pronatalist and antinatalist movements alike.

In the years immediately following World War II, the development efforts that went hand in hand with reconstruction and decolonisation brought renewed attention to population growth rates. A neo-Malthusian paradigm, which during the interwar years had been supported by relatively marginal interests such as eugenics societies and feminist movements, gradually gained adherents within development thinking and practice. At its core was the concern that, should the population growth of developing countries remain unchecked, the result would be world resource shortages and hunger crises, and, potentially, conflict and war. It was feared that development efforts would come to nothing, and, worse, world peace could be jeopardised, in the absence of a large-scale population control effort. As shown by Thomas Robertson, attention to the population-resource dilemma was high in conservationist circles, as illustrated by William Vogt's and Fairfield Osborn's hugely influential books, and was also key in the transition to the later environmentalist movement. ${ }^{16}$ Vogt's 1948 Road to Survival contrasted population growth rates with natural resources, depicting ecological depletion and destruction, whereas Osborn's Our Plundered Planet, published the same year, firmly placed responsibility for the destruction of nature with humanity. ${ }^{17}$

Borgström came into contact with international discussions on conservation, population, and nutrition in the autumn of 1949, when the United Nations (UN) organised a Scientific Conference on the Conservation and Utilization of Resources at Lake Success, New York. In parallel, and at the same venue, the UN Educational, Scientific and Cultural Organization (UNESCO) and the International Union for the Protection of Nature (IUPN) jointly organised the International Technical Conference on the Protection of Nature. ${ }^{18}$ Borgström participated in the latter, making two important acquaintances at Lake Success: Fairfield Osborn and William Vogt. According to Linnér, the interaction was a turning point for Borgström: thereafter, his personal and academic beliefs revolved around a core principle that humanity had to adopt an ecological worldview. ${ }^{19}$ Vogt and Osborn's books were international bestsellers, and Borgström wrote an introduction to the 1949 Swedish edition of Osborn's book Var plundrade planet, ${ }^{20}$ whereas Vogt was published in Swedish the following year, ${ }^{21}$ also advertised in the Norwegian press. ${ }^{22}$ While neither author was translated into Norwegian, writer Georg Brochmann attempted to draw attention to Vogt's work through reviews and lectures in the late 1940s and early 1950s. ${ }^{23}$ Furthermore, while Borgström's experience at the UNESCO conference may indeed have been transformative, his ideas on the populationfood dilemma were not just established but also actively disseminated before Lake Success. 


\section{Borgström and the Norwegian press, the 1950s}

In January 1949, Borgström's research first appeared in the local newspaper Rogaland, which covered an article by Borgström on the world food, population, and resource situation. Introduced as "a remarkable account", Borgström's piece, featured in the "important culture news pages" ${ }^{24}$ raised a conundrum: whereas the Earth could produce food for up to 1,600 million people, the world's population was projected to reach 3,300 million. Population growth would thus outstrip food production, creating a "particularly critical" hunger situation. It was "an immediate political task of the utmost importance to bring about a population stabilisation." However, population control would not suffice. Furthermore, while advances in research and technology might increase agricultural production, the Earth's carrying capacity would soon be reached. The main cause was human: "Despite our dependence upon what the earth produces, there are few items of value we treat so carelessly.... Man has been a very bad caretaker of the earth's riches."

Published a year later, the article "The World Starves" in Nationen was based on an interview with Borgström by the Swedish paper Skanska Dagbladet. ${ }^{25}$ According to Borgström, hunger was a "frightening reality" for large parts of Europe and a massive effort was needed to avoid disaster. Borgström echoed a geopolitically inspired thinking about population growth, resources, and migration, which had become established during the interwar period. ${ }^{26}$ During the nineteenth century, according to this narrative, Europe had come to rely on a gradual export of its surplus populations to other continents through colonisation and migration, as the continent could not feed its growing population. Greater self-sufficiency, technological innovation, and political will to coordinate international efforts were now crucial for resolving the situation. Borgström reminded the readers that John Boyd Orr, director general of the United Nations Food and Agriculture Organisation (FAO) in 1945-1948 had, during the interwar period, argued that international coordination of food resources was needed, to great opposition. ${ }^{27}$ Borgström argued that now, in 1950, the idea was urgently relevant: nearly half of the world's population was starving "A grim fact which raises frightening perspectives." 28

A conference organised by the FAO in September the same year brought Borgström along with a number of experts, politicians, and scientists from 18 different countries to Bergen to discuss challenges in the fishing industries. Of particular concern was whether surplus stocks from Western markets could be exported to developing countries. In his opening statement at the conference, the Norwegian director of Health and head of Norway's FAO committee, Karl Evang, ${ }^{29}$ emphasised the potential of fisheries to solve international hunger. He also asserted that raising people's standard of living was "the only ... basis for a lasting peace." ${ }^{30}$ Borgström, one of the keynote speakers, lectured on "Fisheries and the world's food problems". ${ }^{31}$

Reporting on the FAO conference, Bergens Arbeiderblad summarised Borgström's talk emphasising the potential for increased use of fish to meet the needs 
of a growing population. Bergens Tidende (BT) followed suit, calling Borgström's lecture "rich in perspectives" and arguing that "the oceans [are] the continent of our times." ${ }^{32}$ According to Borgström's geopolitically founded argument, humanity was running out of space after centuries of European expansion, thus the last "continent" to be conquered was the oceans. BT noted the timeliness of the conference, particularly its preamble stating that feeding the world's population was the greatest possible peace effort. The FAO conference was frontpage news in Verdens Gang (VG), which ran the headline "David and Goliath: The FAO's fight against world hunger". ${ }^{33} V G$ 's reporter Asbjørn Barlaup found Borgström's talk "excellent". He wrote that Borgström had ended on a dramatic note: "he looked at his watch and said 'I have now spoken for an hour. During that hour, 2,400 more people were born than who died in the same period." The FAO thus participated in "a giant race, the race against world hunger - or rather, the race against population growth and malnutrition." Near-identical coverage of Borgström's talk appeared in several newspapers ${ }^{34}$ and may have originated in FAO press releases. Indeed, in the Norwegian press in the late 1940s and early 1950s, it was customary not to name reporters. Journalism was only professionalised to a limited degree, and objectivity rather than commentary and analysis represented the ideal, along with a lack of willingness to question matters of reconstruction, foreign and security policy. ${ }^{35}$

There were thus few mentions of Borgström by Norwegian media between 1949 and 1953, and some were related to his work on food conservation. ${ }^{36}$ However, with the 1953 publication of Jorden - vart öde in Sweden, Borgström's emphasis on global matters increased. The Swedish reception was unenthusiastic, and indeed Borgström labelled the critique "the storm". ${ }^{37}$ The book was not translated into Norwegian and thus received no immediate attention. By the end of the year, however, the Norwegian local paper Svelviksposten reported on the publication, with the headline "Every hour, 2,400 new world citizens are born". Borgström's book painted a bleak picture: "If population growth continues, ... the earth could no longer feed its population." Food production must be "mobilised and increased ... to liberate the growing population from destitution or ultimately starvation." ${ }^{38}$ A more comprehensive review appeared in early 1954, written by Frithjof Fluge, a member of the "Oslo School" of philosophers $^{39}$ headed by Professor Arne Næss, who in the 1970s established "deep ecology". ${ }^{40}$ With the title "Overpopulation and world hunger", Fluge lauded Jorden - vårt öde as "top class" "excellently organised, factual and clear" as well as "knowledgeable". ${ }^{41}$ Fluge commended Borgström for revealing technical solutions as illusory ideas: "futile, unless large-scale, efficient birth control is urgently implemented", something which was prevented by the Catholic countries. Fluge concluded that Jorden - vart öde was an "exemplary, precise and straightforward account of humanity's 'to be or not to be"'. Another positive mention appeared in a Morgenbladet review of the 1953 Norwegian edition of Charles Galton Darwin's The Next Million Years. ${ }^{42}$ While Darwin's book received a scathing assessment, ${ }^{43}$ the reviewer judged the topic - the populationfood dilemma - to be vitally important and the book itself to contain "facts 
we cannot afford to ignore". Morgenbladet thus recommended other "excellent and thought-provoking" books, such as Osborn's Our Plundered Planet, but stated that the very best book, however, was Borgström's Jorden - vårt öde, a "trustworthy, science-based portrayal of the situation", revealing the urgency of this dilemma.

The coverage, while positive, was scant, in the Norwegian popular press. In addition, the book was mentioned by writers with a particular concern for Borgström's topic. ${ }^{44}$ However a VG article on population growth, food shortages, and family planning in late 1954 points to a gradually increasing interest in Borgström's core topic, in relation to current affairs. ${ }^{45}$ Largely based on Jorden vart öde, the article presented Borgström's main ideas and underlined the need for birth control, despite Catholic opposition.

In March 1955, Borgström visited Norway, giving a keynote lecture on Jordenvart öde and the world's food problems at the "Agriculture Day". ${ }^{46}$ Several local and national papers reported on the event. Fredriksstads Blad summarised the lecture, highlighting Borgström's call for "balance in nature", ${ }^{47}$ while Nationen focused on the population-food dilemma, soil depletion, and erosion. ${ }^{48}$ Aftenposten's journalist found the talk, which argued that humanity needed a radical, new direction to avoid "the misfortune which threatens our entire existence", to be "very thought-provoking". 49 The following month, Borgström offered a lecture at the student union at the Norwegian Institute of Technology in Trondheim entitled "Can our welfare become universal?". ${ }^{50}$ Nidaros provided detailed coverage in the article "The world's resources soon depleted!" 51 The "population expert" Borgström had painted a gloomy picture of an exhausted planet ruined by mankind's wasteful behaviour, where the issues of Cold War and nuclear threat paled in comparison. The culprits were man and Western industrial civilisation, and the solutions were radical political rethinking, an end to wastefulness, and birth control.

Gradually, from the mid-1950s onwards, Norwegian newspapers presented more stories on the population-food dilemma, international development, and politics, in which Borgström was referred to as an expert. ${ }^{52}$ An example is found in Fadrelandsvennen's "The food problems - the decisive test of our culture", which reiterated Borgström's main points: population growth caused food shortages, birth control was urgently called for, and new directions in development were needed. ${ }^{53}$ Interestingly, such articles were often entirely based on Borgström's ideas, without any presentation of contrasting views, reflective, possibly, of the novelty of these topics for the press and commentators alike. Although the population dilemma received increasing attention, coverage of Borgström in the years 1956-1958 still often focused on his expertise in food conservation. ${ }^{54}$

\section{Borgström in the Norwegian press, 1960-1966: a prophet to the few}

At the outset of the 1960s, Borgström's work initially received attention in Norway in relation to food and the geopolitical considerations of the Cold War. 
Norwegian listeners could tune into Swedish radio to hear Borgström speak on "The food balance between the two great powers". ${ }^{55}$ Stavanger Aftenblad ran a headline about his work in mid-1961, ${ }^{56}$ and the national paper for coastal industries, Fiskaren, followed suit in autumn, summarising an article by Borgström in Svenska Västkustfiskaren claiming that "Tremendous developments in Russian fishing troubles the West". ${ }^{57}$ An article by Borgström on India in the Swedish Göteborgsposten received attention from Rogalands Avis, which claimed that, according to Borgström, India's real problem was overdevelopment, not underdevelopment. The population "has exceeded all reasonable limits". ${ }^{8}$ This conclusion led Bergens Arbeiderblad to agree with Borgström that it was "hardly surprising that nearly the entire population suffered from malnutrition". 59

Borgström's focus on global matters increased further with the 1962 publication of the book Mat för miljarder, which was followed by Gränser för vår tillvaro in 1964, The Hungry Planet: The Modern World at the Edge of Famine in 1965, and Revolution i världsfisket in 1966. Although none of these were published in Norwegian until 1968, attention to Borgström increased steadily, especially in the latter half of the 1960s.

In 1962, Mat för miljarder became the topic of two editorials in Arbeiderbladet, which echoed Borgström's mantra: man's irresponsible behaviour caused soil erosion, deforestation, and explosive population growth. ${ }^{60}$ The solution lay in international population control: "India and many other countries are now begging for help with this - without effect." Arbeiderbladet argued that until priorities changed, no portrayal of the population-food dilemma could be too pessimistic. Borgström's research also became better known through his own active dissemination. Borgström visited Norway in September 1962, lecturing at the University of Oslo on "New ways to measure population density and assess the nutritional standard geographically", ${ }^{61}$ speaking at the Norwegian Chemical Society, and then presenting a lecture on "Arable land, population growth and nutritional standards" at the Student Union of Norway's Agricultural College in Ås. He was interviewed by Adresseavisen, which portrayed Borgström as "a very prominent expert on the world's food supply", who, for a number of years, has hammered home his message "through lectures and particularly well-written books". ${ }^{62}$ Borgström elaborated on the ideas presented in Mat för miljarder, saying food production had to be doubled, even if population control was introduced. "According to Professor Borgström, a new understanding is required - only then the problems may be resolved. He is not a pessimist, but decidedly a realist, and the world ought to listen!"63 Akershus Amtstidende covered Borgström's visit to Ås, noting that "there is reason to expect great interest" in Borgström's talk, given its "current relevance" and the fact that Borgström was "one of the world's foremost experts". ${ }^{64}$ Reporting on the lecture afterwards, the same paper described the audience as "numerous and interested". ${ }^{65}$ Borgström had "explained the [food and population] situation, presenting dry, but frightening facts", describing problems which "White men have not had to consider, thus far." Given Borgström's convincing presentation, "one couldn't help considering these matters more closely." 66 
By 1964, the Norwegian press was reliably noticing Borgström. The 1964 publication of Gränser för vår tillvaro was recognised in nine different local and regional Norwegian newspapers in August and September 1964, all of them publishing the same article, signed G.L., with the headline "Is the World headed for a food crisis of far greater dimensions than today?". ${ }^{67}$ The article stated that Gränser för var tillvaro was the "latest frightening warning" offering an affirmative, Neo-Malthusian answer to the question in its headline. The article reiterated Borgström's message that "coordinated efforts on a gigantic scale were required if humanity was to be rescued".

Within a few months, in January 1965, a leading national newspaper, Morgenbladet, ran a rave review of Gränser för vår tillvaro, calling it "a powerful message" of warning. ${ }^{68}$ The world was on the brink of collapse and the "worst problem was the population's explosive breeding". The book's message caused concern, wrote the reviewer, but "one couldn't doubt that an internationally renowned professor had backing for his claims". Retelling Borgström's ideas rather than analysing them, Morgenbladet's reviewer wished Borgström would disseminate his work in Norway. Soon, NRK radio, the national Norwegian broadcasting corporation, was covering Borgström. The programme Peace With the Earth discussed Gränser för vår tillvaro, as well as Fred med Jorden, by Elisabeth Tamm and Elin Wägner. ${ }^{69}$ Both books argued that modern agriculture was depleting the Earth's resources, pushing the planet to the breaking point, and underlining that, unless humans made peace with Earth, there could be no peace on Earth. ${ }^{70}$ Borgström also appeared on NRK radio to discuss "food and ways of living for a young Europe" with journalist Odd Nordland. ${ }^{71}$ Focusing on population growth, food, and development, Borgström was characterised as "an excellent interviewee" by a listener who was impressed by his "strong personal engagement". ${ }^{72}$

The attention from the Norwegian media continued the following year. In September 1966, Telemark Arbeiderblad, commenting on Borgström's NRK radio lecture, "Food for freedom: New signals in American agriculture", ${ }^{73}$ wrote "World famine ... is upon us, and the situation is rapidly deteriorating." 74 Hangesunds Avis quoted Borgström saying, "our ideas on world food production are marked by the fact that we belong to the 'luxury club' of the world, the rich nations. We urgently need to realise that we are a privileged minority and adjust policies accordingly." 75 Arbeiderbladet also covered the broadcast under the heading "A hungry world". ${ }^{76}$ Later that year, Mat för miljarder also received attention through a discussion of development aid by Nationen ${ }^{77}$ which reiterated Borgström's portrayal of the population-food situation, arguing that aid must be increased.

Borgström's work on fisheries also drew attention in Norway. In late 1964, Tromsø reported on his idea that the region's core product, dried fish, could solve the food crisis. ${ }^{78}$ Two years later, Borgström's Revolusjon i världsfisket received attention in the Bergens Tidende article "World fishing - the new colonialism". ${ }^{79}$ According to $B T$, "Borgström ... consistently and aggressively presented his theses in order to rouse opinion". The fishing industry was enormously 
valuable economically, and while changing its course might be tricky, Borgström's warning was timely: "When he, 15 years ago, warned that the world would go under in famine, many people thought he was exaggerating. Developments since then have confirmed his views." According to BT, Borgström's eye for what needed doing was "almost visionary".

Over the first half of the 1960s, Borgström's message had gained ground, coming to be seen, by mid-decade, as authoritative. In the summer of 1966, Norway's United Nations Association wrote an article based on Borgström's work on world fisheries, which was disseminated widely in local and regional newspapers. Borgström's research showed that most of the fish caught off the coast of North and South America went to animal feed, thus "the huge opportunities for an improved food supply for Latin America, which the ocean offers, to a large extent are lost", ${ }^{80}$ and changes were necessary. The previous year, $V G$ reported on the US introduction of agricultural modernisation and hunger alleviation as conditions for development aid, in an article with the headline "[T] he US threatens the starving countries". ${ }^{81}$ According to VG, the world was headed for famine - this had "repeatedly been pointed out by neutral scientists such as Georg Borgström and Gunnar Myrdal." Apparently, the experts in the US Department of Agriculture had gotten the message and were going to act on it. Similarly, a Morgenbladet op-ed on the futility of aid in the face of overpopulation referred to two books as evidence: William Vogt's Road to Survival and Borgström's “ground-breaking” Jorden, varrt ode. ${ }^{82}$ Diverging views on the food-population dilemma were reflected in the newspapers, but Borgström's views seemed to gain prominence. While a Morgenposten discussion on "The World's food supply situation - optimism and pessimism" argued that research was "greatly marked by the authors' often strongly subjectively grounded assumptions", Grimstads Adressetidende argued Borgström offered "a correct view" ${ }^{83}$ Even in the article "Are we getting close to the great famine?" on scientific disagreements regarding the population explosion, Borgström's view dominated. Featured in several newspapers, the article claimed the world was headed for starvation. ${ }^{84}$ As a Morgenbladet editorial on ecology argued, Borgström was "a lone Scandinavian who understands the problem on a global scale." ${ }^{85}$

Borgström's publications were not only gaining authority but were also becoming points of reference in public debates. Initially introduced in Norwegian public debate by authors with an interest in ecology, such as Frithjof Fluge, and seemingly frequently quoted in newspapers on both the conservative and the left sides of the political spectrum, Borgström's work, by mid-decade, was also embraced by writers associated with the far right. One example is Olav Hoaas, a Nazi sympathiser. Frequently participating in public discussions on population and race, food supply, and self-sufficiency, Hoaas often referred to Borgström's work. "He is no regular hot-headed scientist who makes statements far outside his area of competence", ${ }^{86}$ argued Hoaas, who believed that the population explosion would force people to "soon end ... illusions" about democracy, equality, and human rights. ${ }^{87}$ 


\section{Borgström in the Norwegian press 1967-1968: from prophet to superstar}

From 1967 onwards, the attention to Borgström by the Norwegian press increased sharply, as a result of three main factors: Borgström appeared more regularly on Norwegian radio and television, Borgström visited Norway to give several lectures, and Borgström's Mat för miljarder and Revolution i världsfisket were published in Norwegian. In 1968, media attention to Borgström culminated in his widely covered, veritable tour of Norwegian student unions and lecture halls. An expert on topics of growing appeal to Norwegian audiences, Borgström was increasingly in demand, developing something of a superstar image.

This period of increased attention kicked off with a very favourable review in early 1967 of Revolution $i$ världsfisket, published in Swedish the previous year. ${ }^{88}$ Fadrelandsvennen's reviewer, Andreas Skartveit, embraced Borgström's views to the extent that he simply reiterated them, without comparing them to competing views, and arguing that Borgström's work was supported by "an incredible multitude of facts". Revolution i världsfisket ended with the statement "it's five to midnight", meaning that time was nearly up. According to Skartveit, "This ... is a book many people ought to read", as it would help them understand contemporary conflicts and anticipate future ones. ${ }^{89}$

Borgström returned to NRK radio in mid-February, with three consecutive lectures on "The world food situation". ${ }^{90}$ A number of national and local newspapers covered the broadcasts. Nordlands Framtid argued that Borgström portrayed the world "living hand to mouth", facing famine: "Food reserves are dwindling, while . . every day, another 180,000 humans are born." 91 Nordlys quoted Borgström saying, "It is now too late to drive hunger away - it has come to stay." 92 Fadrelandsvennen summarised the first lecture, calling Borgström's perspectives "gloomy" and "not particularly hopeful", instead presenting "a problem which doubtless will be the main challenge for current generations." "93 Consensus was that "professor Borgström has held a series [on] the very serious problems regarding the world food shortages, gloomily realistic, but also describing the remaining alternatives." ${ }^{44}$ Indeed, radio listeners asked NRK for printed copies of Borgström's lectures, a request that was declined. ${ }^{95}$

In March 1967, NRK again featured Borgström's views, in a debate moderated by Andreas Skartveit, on the provision of development aid to population control efforts. Kenya had recently requested such aid from Norway, and the aid administration was divided. Skartveit's programme brought aid administration representatives together to discuss whether Norway should fund family planning. Population control was becoming increasingly accepted and "even the Roman [Catholic] church has begun reconsidering. Is it about time Norwegian development aid supported family planning?"96 VG argued that "While not everyone views the situation as gloomily as the Swedish Professor Georg Borgström . . . there is general agreement that something needs doing." ${ }^{97}$ In April, Norwegian viewers of Swedish TV could tune in to Borgström discussing world fisheries, ${ }^{98}$ while his three March lectures were replayed on NRK 
radio. In August, a series of three Borgström lectures on "The overdeveloped world" aired on Swedish radio and were also available to Norwegian listeners. ${ }^{99}$ The next month, NRK radio broadcast another three lectures by Borgström, ${ }^{100}$ and several newspapers printed short comments on these. ${ }^{101}$ Borgström also talked on "The Nordic countries' place in a hungry world" on NRK radio on Christmas Eve 1967. ${ }^{102}$

Borgström also contributed to the Norwegian newspapers, publishing two op-eds in Aftenposten in May 1967. In the first, "Deceptions about our world", Borgström delivered his message in strong rhetorical terms: world population was exploding, outstripping food production, and the world needed to take action. His conviction was that it was deeply irresponsible to believe in quick fixes. ${ }^{103}$ In "A second wind for humanity", Borgström argued that, unless humanity chose a new course, global famine would follow. Borgström reiterated that it was "five minutes to midnight" and time was running out. "We will need all ... natural resources, capital, and scientific and technical expertise to ensure the survival of humanity", in addition to population control, global coordination of all aid, and a "general staff for peace". Change was needed when

four billion penniless and hungry people enter and claim their share. That day ... when we ... adjust to this reality may be the proudest moment in the history of our civilisation. But if we neglect to do this, our civilisation will go under ..., and history's judgement will be disgrace. ${ }^{104}$

Two months later, Borgström's article in Norwegian journal Samtiden, "Five minutes to midnight", was called "a strong warning", offering "earthshattering facts on the conflict between population growth and food production", by Rogalands Avis. ${ }^{105}$

In parallel with Borgström's increased visibility in the Norwegian media, his books also received increasing attention, with reviews appearing throughout 1967. Folkets Framtid, issued by the Christian Democratic Party's youth branch, warmly recommended Gränser för vår tillvaro, finding it "a thorough analysis" and "an unusually good book: fantastic in its clear thinking, and grim in its perspectives". ${ }^{106}$ Hartvig Sætra of the Socialist Youth Party reviewed Mat for milliarder and Gränser för vår tillvaro in Orientering, a paper for the political left. Sætra's reviews were glowing, arguing Borgström's works were "the two most important books to have appeared ... since the war." He further called Borgström's views on the population-food dilemma so important that "[n]o politician should be allowed to run for office, and no one should be able to call themselves an academic citizen without solid knowledge of Borgström's documentations." "107 Borgström's work on fisheries also had great appeal in Norway, with Revolution $i$ väldsfisket being reviewed in the fishing industry newspaper Fiskaren in December 1967. Calling the book "a piece of first-class contemporary history", "interesting and thought-provoking", Fiskaren argued that the book should be taught in fisheries schools. ${ }^{108}$ The following month, Finnmarksposten mentioned Borgström's Food for Billions, recently published in the United 
States and which had been "characterised as one of the most significant books in fifty years." The paper hoped a Norwegian translation would soon appear. ${ }^{109}$

Indeed, in autumn 1967, Norwegian publisher Gyldendal announced that Mat för miljarder would soon feature in their series, Gyldendals Kjempefakler, to which the media responded with enthusiasm. ${ }^{110}$ Sixteen newspapers reported that Borgström would be translated into Norwegian, with Drammens Tidende og Buskeruds Blad calling Borgström a "scientist and alarm clock", ${ }^{111}$ and Nationen saying that he "had made the entire world listen to his gloomy forecasts." ${ }^{112}$ Evidence of the increasing media interest were the portrait interviews on Borgström that began appearing. Dagningen printed photos of Borgström in his US home, arguing that the "international doomsday prophet" was no "empty sensationalist": his work had been read by President Kennedy and he now participated in President Johnson's council on nutrition. Arguing that Borgström "should be well-known to Norwegians through his many eminent radio lectures", ${ }^{113}$ the paper reiterated his main ideas: that spaceship earth must be prioritised over the space and nuclear races, and that population control was necessary.

The increasing appetite for Borgström's message was also reflected in Norwegian student politics and debates. Socialist Berge Furre elaborated upon Borgström's work in a talk on consumer society to Bergen's student union in autumn 1967. ${ }^{114}$ Also, Borgström's name featured heavily in the elections to student union committees in 1968. In November 1967, the Student Union at the Agricultural College in As elected Svein Sundsbø as president, with a 1968 seminar programme including Borgström. ${ }^{115}$ Reported in Aftenposten ${ }^{116}$ and Akershus Amtstidende, Borgström, "a world capacity", would talk on "The World food situation". ${ }^{117}$ Days later, the Bergen Student Union elected conservative Leif Neergaard as president, also with a programme featuring Borgström, ${ }^{118}$ with a talk on "Space for billions, food for millions". ${ }^{119}$ Lastly, Oslo's Norwegian Students' Society elected conservative Georg Apenes, whose programme, including Borgström's talk "A crusade for the survival of humanity", also received attention from several national and local papers. ${ }^{120}$

In January 1968, Gyldendal launched its much-awaited book series featuring Mat för miljoner, just ahead of Borgström's upcoming lecture tour, and an extensive coverage followed. Norway's Director of Health Karl Evang, an avid supporter of Borgström's views, introduced the book, saying that it had "received attention all over the world". ${ }^{121}$ Evang lauded Borgström's book, arguing that the population-food situation had "never before been so broadly studied". Nationen reported that unless "radical actions were taken", crisis was sure to result. Aftenposten judged Borgström's book to be among the most important in the Gyldendal series. ${ }^{122}$

The book launch was followed by a flurry of reviews. According to Haugesunds Avis, Mat för miljoner was "clearer than everything else we have read on this topic" and should force politicians to act. ${ }^{123}$ Vart Land stated that it was impossible to contradict Borgström's findings. While his "gloomy perspectives should be well-known to Norwegian radio listeners", the book format provided more 
information and data. ${ }^{124}$ Finnmarken also reviewed the book positively, ${ }^{125}$ as did Fadrelandsvennen, ${ }^{126}$ and in Rana Blad, the review "Food - or hunger for billions" found Mat for milliarder "so important everyone ought to know it." ${ }^{127}$ In March 1968, Revolution i världsfisket was also translated into Norwegian. A very favourable review in Fiskaren argued that the book was "highly relevant" given the circumstances in Norwegian fisheries. ${ }^{128} \mathrm{VG}$ published a rave review, stating, "Let it be said at once: this is one of the most interesting publications ever to have been published in Norwegian." 129

Throughout winter 1968, Borgström's visit to Norway was eagerly awaited by Norwegian media. In January, Aftenposten and BT articles anticipated that Borgström's talks would be among the term's most popular in Bergen. ${ }^{130}$ His Oslo talk was also expected to draw great interest and a large audience. ${ }^{131} \mathrm{Sev}-$ eral newspapers ran short articles ahead of Borgström's lecture at the Agricultural College in Ås, with Nationen calling the lecture "the highlight of this term's programme", ${ }^{132}$ and Vart Land interviewing Ås Professor Knut Breirem about Borgström. ${ }^{133}$

Expectations ran high, with several national and local newspapers covering Borgström's arrival in Norway and the upcoming lectures. ${ }^{134}$ NRK reran Borgström's radio lecture series from 1967, ${ }^{135}$ and upon his arrival in Oslo, Borgström was featured on the radio debating "Are the oceans our future?" with Andreas Skartveit, and on the TV programme Food for billions. ${ }^{136}$ Borgström's NRK appearances were given thorough coverage by the press. ${ }^{137}$

Borgström's lecture tour began in Oslo's student union on Saturday 16 March. Moved to the largest auditorium in Folkets Hus to accommodate the crowds, the lecture's media coverage was somewhat overshadowed by the simultaneous announcement of the Norwegian crown prince's engagement. Soon, however, Morgenbladet ran a long article recounting Borgström's message, calling it "one of the most serious topics the Student Union had dealt with". ${ }^{138}$ Arbeiderbladet called it "a lecture with unusual force and quality", which silenced the entire lecture hall, followed by a "long, engaged and, at times, good debate." ${ }^{139}$ Borgström argued "a crusade against hunger and destitution" was needed to ensure the survival of humanity. ${ }^{140}$

Borgström's lecture at the Ås Student Union two days later was also a roaring success, drawing record crowds. Borgström had encouraged the students to "face the facts, and start a campaign for the survival of humanity." "The following day, Borgström lectured on fish and world food problems at the Norwegian School of Economics in Bergen, ${ }^{142}$ also finding time to talk on world population and food problems at the Norwegian Peace Association. ${ }^{143}$ On Wednesday 20 March, Borgström travelled to Trondheim, lecturing on "The use of sea resources" at the Norwegian Institute of Technology ${ }^{144}$ and "Five minutes to midnight" at the student union. ${ }^{145}$

Borgström's tour of Norway was clearly a success in terms of both media attention and the increasing references to his message in Norwegian public debate. In the late 1960 s, a wide range of commentators, discussing a wide range of matters, referred to Borgström. Four partially interrelated topics 
stand out: fisheries, agriculture, international development, and conservation/ environment.

While Revolution i världsfisket created attention, Borgström's work was also referred to as authoritative in debates over issues affecting Norwegian fisheries in the 1960s, such as surplus catches. ${ }^{146}$ Discussions of fisheries within an international context also drew on Borgström's authority. For example, Hartvig Sætra cited Borgström in arguing that the state should intervene to guarantee that all fish caught would be used as food, with none wasted. ${ }^{147}$ Debates over agriculture also referred to Borgström's research. A Morgenbladet editorial on soil, for example, was based on Borgström's Gränser för vår tillvaro. ${ }^{148}$ Calling soil humanity's most important asset, the editorial reiterated Borgström's call for conservation. Borgström's views were also echoed in articles on Norwegian agriculture in an international context, as when Arbeiderbladet argued that agricultural policy and practice must take into account the population explosion. ${ }^{149}$ Borgström's call for arable land conservation and self-sufficiency also resonated with Nationen, which argued, "It's time we protect farmland" and "let's not conquer space, only to lose earth." 150

In the international development debates in Norway over the populationfood dilemma, Borgström's research was frequently used to underscore pessimistic interpretations. Oluf Berentsen argued in Dagbladet, "It is no longer a private matter how many children one should have. Over time, life becomes more valuable with birth control, even sterilisation, than without." ${ }^{151}$ Philosopher Bernt Vestre called Borgström's research "authoritative" and "very well-documented", ${ }^{152}$ indicating agreement about the need to act. Vestre also cited Borgström as an authority on more divisive issues such as birth control, the effects of imperialism and colonialism, ${ }^{153}$ and foreign aid. ${ }^{154}$ In BT, Bredo Berntsen claimed "population growth, coupled with destruction of nature, represents the world's number 1 problem", ${ }^{155}$ as was clear from the work of worldfamous researchers Borgström, Julian Huxley, and Gunnar Myrdal, who had "propagated changed understandings of the world's capacity, and population control." Berntsen also mentioned Rolf Edberg's 1966 Et støvgrann som glimter. While the names of Borgström, Huxley, and Myrdal, as well as Charles Galton Darwin, were relatively frequently associated, ${ }^{156}$ Edberg's name only appeared this once in relation to Borgström's. Clearly, Borgström was not alone in his dissemination of the population-food dilemma. His views, however, were seen as scientific and thus reliable, scarcely challenged and only rarely contrasted with others. ${ }^{157}$ As an op-ed in Namdal Arbeiderblad stated, "there is no shortage of warnings about how our world will end", but the "thought-provoking" Mat för miljarder was written by Borgström, one of the world's foremost "development pessimists". ${ }^{158}$ While a Nordlys editorial argued that Borgström proved that "a hunger curtain" had descended, threatening peace, ${ }^{159}$ the Norwegian Peace Council begged the government to heed the advice of internationally renowned expert Borgström, as the world had only ten years left. ${ }^{160}$ In Orientering, Hartvig Sætra did not hesitate to weigh in on Borgström's side. Having "studied the food supply matter very thoroughly, both as a politician and a 
biologist, and having read Georg Borgström, I am more convinced than ever ... that pervasive political changes are necessary, both in the developing countries and in the West. And this is urgent." ${ }^{\prime 16}$

\section{The circulation of Borgström's message in the Norwegian public sphere: when, how, and with what consequences?}

Examining the circulation of Borgström's message in the Norwegian public sphere in the 1950s and 1960s, this chapter has looked at the timing of, attention to, and impact of Borgström. Regarding timing, the attention paid to Borgström's message on the population-food dilemma beginning in the late 1940s onwards, preceded by two decades that paid to Ehrlich's The Population Bomb and Hardin's "The Tragedy of the Commons". And yet the names Ehrlich and Hardin were staples of postwar international debate on population, resources, and environment, whereas those of Borgström, like Osborn's and Vogt's, were rather related to the earlier, interwar conservationist movement. Hence, Borgström's ideas circulated in Norway more or less simultaneously with those circulating internationally within the conservationist milieu but well ahead of ideas that later have been ascribed key importance for environmentalist movements. Further, Borgström's core ideas initially received attention from actors with a particular interest in his message, such as ecosophy philosopher Fluge, Director of Health Karl Evang, and journalist Andreas Skartveit. Throughout the time period, however, the appeal of Borgström's message grew, with a multitude of actors, seemingly regardless of their politics, disseminating or referring to his views. The key to Borgström's media success and eventual superstar status in Norwegian public debate was the fact that his ideas, which dealt with a range of issues, appealed to ever-new groups of people. Further, Borgström's research dealt with matters pertaining to two Norwegian core industries: agriculture and fisheries. Thus Borgström evoked interest in groups such as the Centre and Labour parties and their voters, and in regions where farming and fishing were key industries. Throughout the 1960s, Borgström increasingly focused on the international ramifications of these industries, as well as international development and redistribution - topics of growing concern to new generations of students and to parties on the left side of the political spectrum.

Finally, with respect to the impact of the circulation of Borgström's message in Norway, the matter warrants further study. Several actors espoused the population-food dilemma in public debate, and thus more research is required to establish the importance of Borgström's seeming superstar status in public debate. What is clear, however, is that the flurry of attention to Borgström's person and ideas, culminating in his 1968 tour of Norway's student unions, eventually led to his direct participation in the launching of environmental movements such as Fremtiden $i$ vare hender during the 1970 s. ${ }^{162}$ This points to an important finding: whereas the historiography of environmentalism often understands the late 1960s and early 1970s as the period when there was a breakthrough in "ecological crisis awareness", which spurred the modern 
environmentalist movements, ${ }^{163}$ Borgström's focus on ecology clearly predated this - as did the circulation of his ideas in Norwegian media. Although Borgström received Norwegian media attention whenever the issues of farming, fisheries, and international development featured in current affairs, his views of nature conservation remained at the very core of his work from the late $1940 \mathrm{~s}$ onwards and thus were part of any coverage of Borgström.

A study of Borgström illustrates how the circulation of knowledge within one country's media should include international perspectives, in this case, in order to identify the connections between local issues and global debates over population and food. Studying global knowledge circulation in conjunction with investigations of environmental concerns may help historians lengthen and broaden their inquiries, to not only focus on the point at which environmental concerns were translated into political actions but also to trace relationships among affiliated areas and to earlier periods.

\section{Notes}

1 Svein Sundsbø, Korn. Kraft. Klima: En personlig fortelling om samfunn og politikk gjennom 210 år (Oslo: Alm Media, 2018), 121.

2 Johan Östling, "Vad är kunskapshistoria?” Historisk tidskrift 135, no. 1 (2015): 109-119. See also Johan Östling, Erling Sandmo, David Larsson Heidenblad, Anna Nilson Hammar, and Kari Nordberg, eds., Circulation of Knowledge: Explorations in the History of Knowledge (Lund: Nordic Academic Press, 2018).

3 Paul Ehrlich, The Population Bomb (New York: Buccaneer Books, 1968).

4 Garrett Hardin, “The Tragedy of the Commons”, Science 162, no. 3859 (1968): 1243-1248.

5 See, for example, Mattias Tydén, "The Scandinavian States: Reformed Eugenics Applied", in The Oxford Handbook of the History of Eugenics, eds. Alison Bashford and Phillippa Levine (Oxford and New York: Oxford University Press, 2010); Per Haave, "Tvangssterilisering i Norge: En velferdsstatlig politikk i sosialdemokratisk regi?" in Frihed, lighed og tryghed: velfordspolitik $i$ Norden, eds. Hilda Rømer Christensen, Urban Lundberg, and Klaus Petersen (Aarhus: Jysk Selskab for Historie, 2001).

6 Alison Bashford, Global Population: History, Geopolitics, and Life on Earth (New York: Columbia University Press, 2014).

7 Matthew Connelly, Fatal Misconception: The Struggle to Control World Population (Harvard: Belknap Press, 2008).

8 Rickie Solinger and Mie Nakachi, eds., Reproductive States: Global Perspectives on the Invention and Implementation of Population Policy (Oxford: Oxford University Press, 2018).

9 Thomas Robertson, The Malthusian Moment: Global Population Growth and the Birth of American Environmentalism (New Brunswick: Rutgers University Press, 2012).

10 Sunniva Engh, "The Conscience of the World? Swedish and Norwegian Provision of Development Aid", Itinerario 33, no. 2 (2009): 65-82; Sunniva Engh, "The Rockefeller Foundation, Scandinavian Aid Agencies and the 'Population Explosion"', in American Foundations and the European Welfare States, eds. Klaus Petersen, John Stewart, and Michael Kuur Sørensen (Odense: Syddansk Universitetsforlag, 2013), 181-202.

11 See, for example, David Larsson Heidenblad, "Överlevnadsdebattörerna: Hans Palmstierna, Karl-Erik Fichtelius och miljöfrågornas genombrott i 1960-talets Sverige”, in Efterkrigstidens samhällskontakter, eds. Fredrik Norén and Emil Stjernholm (Lund: Mediehistoriskt arkiv, 2019), 157-184.

12 Björn-Ola Linnér, The World Household: Georg Borgström and the Postwar PopulationResource Crisis (Linköping: Linköping University Press, 1998).

13 Ibid., 24-28. 
14 See the National Library's web pages, accessed 5 September 2019, www.nb.no/samlingen/ aviser/. The collection is available online at bokhylla.no. The search option can be found at https://beta.nb.no/search. All translations from the original Norwegian are the author's.

15 Searches have been carried out using both the Swedish and Norwegian spellings of Borgström's name (i.e., "Georg Borgström" and "Georg Borgstrøm”).

16 Thomas Robertson, "Total War and the Total Environment: Fairfield Osborn, William Vogt, and the Birth of Global Ecology", Environmental History 17, no. 2 (2012): 336-364.

17 Paul Warde, Libby Robin, and Sverker Sörlin, The Environment: A History of the Idea (Baltimore: Johns Hopkins University Press, 2018), 6-24.

18 Anna-Katharina Wöbse, “The World After All Was One': The International Environmental Network of UNESCO and IUNP, 1945-1950", Contemporary European History 30, no. 3 (2011): 331-348.

19 Linnér, The World Household.

20 Fairfield Osborn, Vår plundrade planet, introduction by Georg Borgström (Stockholm: Natur och Kultur, 1949).

21 William Vogt, Kan jorden föda oss? (Stockholm: Albert Bonniers förlag, 1950).

22 Book ad in Dagbladet, 27 November 1950.

23 Bredo Berntsen, Gronne linjer. Natur- og miljøvernets historie i Norge (Oslo: Unipub, 2011), 99-100, 115-117.

24 “Å virkeliggiøre frihet fra nød ingen lett oppgave”, Rogaland, 5 January 1949.

25 "Verden sulter", Nationen, 20 January 1950.

26 Bashford, Global Population.

27 John Boyd Orr, As I Recall: The 1880s to the 1960s (London: Macgibbon and Kee, 1966), $114-122$.

28 "Verden sulter", Nationen, 20 January 1950.

29 Evang had been present at FAO's founding in 1943. David Murray Lyon, "The Hot Springs Conference", Proceedings of the Nutrition Society 2, no. 3-4 (1944): 163-176.

30 "Havets rikdom må hjelpe til med å løse verdens hungerproblemer", Bergens Arbeiderblad, 25 September 1950.

31 "Kan sildeoverskuddet komme Asias og Afrikas befolkning til gode?" Bergens Tidende, 23 September 1950.

32 "Havet vår tids continent", Bergens Tidende, 25 September 1950.

33 "David og Goliat. FAOs kamp mot verdenshungeren", VG, 27 September 1950.

34 "Ernæringsproblemene øker fiskens betydning som menneskeføde", Vart Land, 26 September 1950; "Ernæringsproblemene i verden øker fiskens betydning som menneskeføde", Lofotposten, 26 September 1950; "Vår tids største fredsoppgave å mette 2,5 milliarder munner", Nationen, 26 September 1950.

35 The postwar period saw a gradual professionalisation of journalism, with formal training established in 1951. Rune Ottosen, Lars Arve Røssland, and Helge Østbye, Norsk pressehistorie (Oslo: Det Norske Samlaget, 2012), 122-123, 150-154.

36 See "Radio", Arbeiderbladet, 28 September 1950; “Årsmøte i Konservesfabrikkenes Forening”, Norsk Handels- og Sjøfartstidende, 2 April 1951.

37 Linnér, The World Household, 105.

38 Svelviksposten, 15 December 1953.

39 Harald Ofstad, "Objectivity of Norms and Value-Judgments According to Recent Scandinavian Philosophy", Philosophy and Phenomenological Research 12, no. 1 (September 1951): 42-68.

40 Peder Anker, “Arne Næss sett utenfra”, Samtiden 4 (2002): 4-19.

41 F. Fluge, "Overbefolkning og verdenshunger”, VG, 5 February 1954; Bergens Arbeiderblad, 6 February 1954.

42 Charles Galton Darwin, Hvordan blir verden om én million år? (Oslo: Cappelen, 1953).

43 E. Pierstorff, "Lettbent fysiker om fremtiden", Morgenbladet, 28 April 1954.

44 A possible reason for this seeming lack of interest could be that reviews would appear in academic journals rather than dailies; however, a search of journals in bokhylla.no produces one result - a mention of Borgström in a report on the FAO conference. "Fangst, 
distribusjon og konservering av sild", Tidsskrift for hermetikkindustri 11 (November 1950): 569-578.

45 M. Gulbrandsen, "I den ellevte time!" VG, 2 October 1954.

46 "Bondestevnet i Østfold, Sarpsborg”, Fredriksstads Blad, 18 March 1955.

47 "Naturen krever balanse", Fredriksstads Dagblad, 25 March 1955.

48 "Vi driver sløseri med jord og energi", Nationen, 25 March 1955.

49 "Vår tids spesialisering truer med å undergrave vår eksistens", Aftenposten, 25 March 1955.

50 "Studentersamfundet i Trondhjem", Adresseavisen, 21 April 1955.

51 “Jordens ressurser snart uttømt!” Nidaros, 25 April 1955.

52 See "Utvikling på avveier?" Sandefjords Dagblad, 28 April 1955; "Streiftog i utlandet", Morgenbladet, 13 April 1957.

53 T. Helle, "Levnedsmiddelproblemet - vår kulturs avgjørende prøve", Fadrelandsvennen, 12 September 1955.

54 See, for example, "Konservesindustrien letter tungt arbeide for husmoren", Morgenbladet, 2 March 1956; "Norge følger ikke med i utviklingen på matvarefronten", Morgenposten, 3 March 1956.

55 "Radioprogrammet i dag og i morgen", Adresseavisen, 23 September 1960.

56 “Sovjet bygger nå ut sitt hav-imperium”, Stavanger Aftenblad, 19 June 1961.

57 "Voldsom utvikling i det russiske fiske uroer Vesten", Fiskaren, 9 August 1961.

58 "Indisk overutvikling", Rogalands Avis, 4 July 1961.

59 "Indisk overutvikling", Bergens Arbeiderblad, 10 July 1961.

60 "Seks tusen millioner mennesker", Arbeiderbladet, 12 July 1962 and 13 July 1962.

61 "Hovedstaden", Nationen, 30 August 1962;"'Gjesteforelesning”, Morgenbladet, 30 August 1962.

62 "Vesten har vunnet i historiens lotteri", Adresseavisen, 7 September 1962.

63 Ibid.

64 "Studentsamf. i Ås", Akershus Amtstidende, 7 September 1962.

65 "Verdens ernæringsproblemer", Akershus Amtstidende, 10 September 1962.

66 Ibid.

67 "Går verden mot en matvarekrise av langt større dimensjoner enn i dag?" Dalane Tidende, 21 August 1964; Hadeland, 22 August 1964; Valdres, 25 August 1964; Brønnøysunds Avis, 28 August 1964; Østlands-posten, 29 August 1964; Hardanger, 29 August 1964; Harstad Tidende, 3 September 1964; Møre, 8 September 1964; Akershus Amtstidende, 23 September 1964.

68 "Grenser for vår tilværelse", Morgenbladet, 30 January 1965.

69 "Programmene", VG, 4 February 1965.

70 Hilde Ibsen, Menneskets fotavtrykk: En økologisk verdenshistorie (Oslo: Tano Aschehoug, 1997), 100.

71 "Radio og TV", Adresseavisen, 18 February 1965.

72 "Mat og levemåte for et ungt Europa”, Fedrelandsvennen, 27 February 1965.

73 "Radio", Nationen, 1 September 1966.

74 "Verdenshungeren er den store katastrofe", Telemark Arbeiderblad, 6 September 1966.

75 "Radio og TV i kveld", Hangesunds Avis, 6 September 1966.

76 "En sulten verden”, Arbeiderbladet, 6 September 1966.

77 "Sirkus framfor brød", Nationen, 21 December 1966.

78 “Tørrfisk - verdens redning hevder svensk-amerikaner", Tromsø, 9 December 1964.

79 "Verdensfisket - den nye kolonialismen", Bergens Tidende, 30 April 1966.

80 "Dyrefór eller menneskeføde?" Folkets Framtid, 20 August 1966.

81 "USA truer sult-landene", VG, 4 December 1965.

82 B. Vogt, "Hjelpen som går opp i røk”, Morgenbladet, 18 December 1962.

83 "Matmangelen på jorden”, Grimstad Adressetidende, 22 January 1963; "Verdens forsyningsproblem - optimisme og pessimisme", Morgenposten, 19 July 1963.

84 "Nærmer vi oss den store hungerskatastrofe?" Sandefjords Blad, 10 December 1965; Nationen, 14 December 1965; Nordlands Framtid, 14 January 1966; Grimstad Adressetidende, 1 February 1966.

85 “Hva er økologi?” Morgenbladet, 8 March 1965. 
86 O. Hoaas, "Det var tyskerne, ikke nazismen vi kjempet mot", Nordlands Framtid, 26 October 1966.

87 O. Hoaas, "Illusjonenes sammenbrudd", Lofotposten, 3 November 1966.

88 A. Skartveit,"Revolusjon i verdsfisket", Fodrelandsvennen, 18 January 1967.

89 Ibid. See also A. Skartveit, "Revolusjon i verdsfisket", Bergens Tidende, 16 March 1967.

90 "Programmene", VG, 15 February 1967.

91 "Lever vi fra hånd til munn?" Nordlands Framtid, 9 February 1967.

92 "Hungeren blir permanent', Nordlys, 10 February 1967.

93 "Sett og hørt", Fedrelandsvennen, 15 February 1967.

94 "På bølgelengde", Helgeland Arbeiderblad, 18 February 1967.

95 "NRK sier prinsipielt NEI til å trykke opp foredrag”, Arbeiderbladet, 22 February 1967.

96 "For og imot planlegging av familien", Rogalands Avis, 20 March 1967.

97 "Radiodebatt i kveld: Familieplanlegging og utviklingshjelp", VG, 20 March 1967.

98 "TV", Moss Dagblad;"Radio Listings", Harstad Tidende, 21 April 1967.

99 "Radio", Moss Dagblad, 12 August 1967.

100 "Radio", Harstad Tidende, 21 September 1967.

101 "Tre svenske foredrag om vår fattige rikdom", Bergens Arbeiderblad, 21 September 1967; "Overutvikling", Stavanger Aftenblad, 30 September 1967.

102 "Radio", VG, 23 December 1967.

103 G. Borgström, "Villfarelser om vår verden”, Aftenposten, 2 May 1967.

104 G. Borgström, "Ny giv for menneskeheten", Aftenposten, 5 May 1967.

105 "Fra nasjonalfølelse til Beatles i Samtiden”, Rogalands Avis, 24 July 1967.

106 “Kan ikke matvareproduksjonen økes særlig?” Folkets Framtid, 27 May 1967.

107 H. Sætra, "Mat for milliarder", Orientering, 11 November 1967 and 2 December 1967.

108 T. Lockert, "Revolusjon i verdensfiskeriene", Fiskaren, 28 December 1967.

109 J. Gustavsen, "Sult og overbefolkning", Finnmarksposten, 9 January 1968.

110 "Gyldendals billigbøker", Morgenbladet, 1 September 1967.

111 "Fra utlandets jordbruk", Drammens Tidende og Buskeruds Blad, 15 September 1967.

112 “Brennaktuelt fra hele verden”, Nationen, 2 September 1967.

113 "Vestens folk slikker fløten av verdens ressurser", Dagningen, 26 October 1967.

114 "Radikalt resolusjonsforslag lider nederlag i Studentersamfunnet", Morgenavisen, 2 October 1967.

115 “Svein Sundsbø formann i Studentsamfunnet ved NLH”, Rogaland, 20 November 1967.

116 "Vårens program i Studentersamfunnet i Ås”, Aftenposten, 23 November 1967.

117 "Valg i Studentsamfunnet i Ås", Akershus Amtstidende, 24 November 1967.

118 "Bergensstudentene valgte konservativt styre i vårsemesteret", Dagbladet, 25 November 1967.

119 "Konservativt styre valt i Studentersamfunnet i går”, Bergens Arbeiderblad, 25 November 1967.

120 "Nytt konservativt semester for studentene", Dagbladet, "Rekordvalg i Studentersamfundet", Arbeiderbladet, "Ny konservativ", Morgenbladet, 27 November 1967.

121 "Standardverk og faglitteratur i Gyldendals 'Kjempefaklene"”, Nationen, 19 January 1968.

122 "Ny, vektig billigserie", Aftenposten, 19 January 1968.

123 E. Tjønneland, "Kjempe-fakkel forut", Haugesunds Avis, 25 January 1968; "Kjempefaklene”, Lofotposten, 26 January 1968.

124 J. Lauritzen, “Hungerteppet deler verden og kan lede til ny krig”, Varrt Land, 29 January 1968.

125 "Mat for milliarder", Finnmarken, 13 March 1968.

126 S. Benneche, "Befolkningseksplosjon fører til uunngåelig hungerkatastrofe", Fadrelandsvennen, 13 February 1968.

127 A. Jensen, "Mat - eller sult for milliarder", Rana Blad, 1 February 1968.

128 "Revolusjon i verdens fiskerier", Fiskaren, 11 March 1968.

129 "Fiskeri-revolusjonen fascinerende drama", VG, 14 March 1968.

130 "Debatt om kirken i Studentersamfunnet", Bergens Tidende, 15 January 1968; "Studentersamfunnstyret i Bergen har godt program”, Aftenposten, 16 January 1968.

131 "Dynamisk konservatisme i Studentersamfundet", Aftenposten, 17 January 1968.

132 "Professor Borgström til Studentsamfunnet i Ås”, Nationen, 16 March 1968. 
133 "Ernæringsproblemene et spørsmål om menneskelig solidaritet", Vart Land,3 February 1968.

134 "Sultens problem i Kroa", VG, 15 March 1968; "Ikke millioner, men milliarder", Dagbladet,16 March 1968;"Protein - fremtidens verdimåler”, Bergens Tidende, 16 March 1968.

135 "Radio", Valdres, 7 March 1968.

136 “TV og Radio", Tidens Krav, 14 March 1968.

137 See for example "Kan havets rikdommer gi mat til milliarder?" Nationen, 14 March 1968; Rogaland, 15 March 1968; Nordlys and Vårt Land, 16 March 1968; Lofotposten, 16 March 1968; "Mat for milliarder", Arbeiderbladet, 18 March 1968.

138 "Verdensomspennende hungerkatastrofe innen de neste ti år", Morgenbladet, 18 March 1968.

139 "Borgström maner til krig for menneskehetens framtid", Arbeiderbladet, 19 March 1968.

140 "Felttog mot nød og sult", Nordlands Framtid, 18 March 1968; "Et felttog for å redde menneskeheten", Nordlandsposten, 19 March 1968.

141 "Fullstendig feil bilde av u-landene", Dagbladet, 19 March 1968.

142 "Gjesteforelesning”, Bergens Arbeiderblad, 14 March 1968.

143 "Oppdragelse til fred på møter til våren”, Bergens Tidende, 7 March 1968.

144 "Gjesteforelesning ved NTH”, Adresseavisen, 15 March 1968.

145 "Verdenshavenes ressurser mobilisert for å 'fete opp' velfødde mennesker", Adresseavisen, 21 March 1968.

146 Åsmund Lund Olsen, "På sporet av den tapte sild” (MA diss., University of Oslo, 2019).

147 H. Sætra, "Er det utopi å gi mat til dei sultne?" Finnmark Dagblad and Tromsø, 2 February 1968; Loftoposten, 5 February 1968; Fiskeribladet, 13 February 1968.

148 E. Høie, "Jordsmonnet - menneskenes viktigste aktivum”, Morgenbladet, 6 June 1967.

149 O. Nordland, "Norsk jordbruk i samtidsperspektiv", Arbeiderbladet, 19 January 1967.

150 T. Ytre, "Jord, du er vår moder", Nationen, 3 November 1967.

151 O. Berentsen, "Befolkningseksplosjon og levemuligheter", Dagbladet, 23 August 1967.

152 B. Vestre, "Overbefolkning, fattigdom og forskjellige julenisser", Dagbladet, 19 August 1967.

153 "U-hjelp: hjelp eller utbytting?” Arbeiderbladet, 17 November 1967.

154 “300 millioner underernærte barn”, Stavanger Aftenblad, 3 October 1967; Fadrelandsvennen, 6 October 1967; Adresseavisen, 6 December 1967.

155 B. Berntsen, "Befolkningsøkningen et problem også for Norge”, Bergens Tidende, 21 September 1967.

156 See notes 46, 87, 162, 166 .

157 A rare example is found in “År 2000 blir et eventyr”, VG, 3 April 1967.

158 P. Aasen, "De rike land skal stilles på prøve!” Namdal Arbeiderblad, 15 January 1968.

159 "Et hungerteppe senkes?” Nordlys, 3 February 1968.

160 S. Lid Larssen and L. Lid Larssen,"Perspektivløs fremtid”, Arbeiderbladet, 9 November 1967.

161 H. Sætra, "Radikal debatt", Orientering, 11 November 1967. See also H. Sætra, "Svar frå ein "populist»", Orientering, 17 February 1968.

162 Ane Bjølgerud Hansen, "Oppbrudd fra forbrukersamfunnet: Bevegelsen Framtiden i våre hender 1974-1982” (MA diss., University of Oslo, 2007), 20-27.

163 This is pointed out in David Larsson Heidenblad, "Ett ekologiskt genombrott? Rolf Edbergs bok och det globala krismedvetandet i Skandinavien 1966", Historisk tidsskrift 95, no. 2 (2016): 245-266, which also offers an excellent overview of research on Scandinavian environmentalism. 